\title{
Effect of naloxone and pulsatile luteinizing-hormone-releasing hormone infusions on oestradiol-induced luteinizing hormone surges in immature gilts
}

\author{
G. Küneke, N. Parvizi and F. Elsaesser ${ }^{*}$ \\ Institut für Tierzucht und Tierverhalten (FAL), Mariensee, 3057 Neustadt 1, Germany
}

\begin{abstract}
The aim of the study was to understand why immature 60-day-old gilts produce delayed low amplitude luteinizing hormone ( $\mathrm{LH}$ ) surges in response to oestradiol benzoate. In Expt 1, gilts $(n=36)$ were challenged with oestradiol benzoate and subsequently received either no further treatment or were infused with saline or various doses of the opioid antagonist, naloxone, for 6-48 h during the expected LH surge (48-96 $\mathrm{h}$ after oestradiol benzoate). No differences were observed among groups in the magnitude or duration of the LH surge. In contrast to the other groups, LH concentrations in gilts infused for $48 \mathrm{~h}$ with naloxone did not decrease after the surge period. In Expt 2, gilts $(n=34)$ were challenged with oestradiol benzoate or sesame oil and subsequently received pulses of luteinizing-hormone-releasing hormone (LHRH) or saline solution during the expected surge period. Two other groups were fed methallibure to pharmacologically suppress the oestradiol benzoate-induced LH surge. In addition, one of these groups was given pulses of an LHRH agonist (LHRH-A) during the surge period. Within $2 \mathrm{~h}$ of the start of pulsatile LHRH infusion, $\mathrm{LH}$ increased in sesame oil-treated gilts, but not in oestradiol benzoate-treated gilts, suggesting that the pituitary responsiveness to LHRH in immature gilts is decreased by oestrogen before the onset of the LH surge. Pulsatile LHRH infusion did not enhance the amplitude of oestradiol benzoate-induced LH surges nor did it advance its onset. Feeding methallibure suppressed the oestradiol benzoate-induced LH surge. LHRH-A infusion of methallibure-treated gilts produced LH surge amplitudes similar to those of controls, but much below those previously observed by us in pubertal gilts or by others during a similar LHRH-A treatment regimen in mature gilts. In addition, the biphasic surge response to oestradiol benzoate, typical for the immature gilt, was abolished in LHRH-A-treated gilts. We suggest that oestradiol fails to generate mature $\mathrm{LH}$ surges because the gonadotrophs of the immature gilt cannot respond to enhanced LHRH secretion during the surge period in an adult-like manner.
\end{abstract}

\section{Introduction}

Available evidence suggests that the ability of gilts to respond to oestrogen stimulation with a luteinizing hormone (LH) surge changes gradually as a function of age. The maturation of the positive oestrogen-feedback mechanism in gilts involves a change in the amplitude and the timing of the LH response: immature 60-day-old gilts show delayed, low amplitude LH surges in response to exogenous oestradiol benzoate in contrast to pubertal gilts (Elsaesser and Foxcroft, 1978; Dial et al., 1984; Fleming and Dailey, 1985). Another maturational event relates to the ability of prepubertal gilts to respond to increased oestrogen concentrations with circadian surges of $\mathrm{LH}$, that is lost as puberty occurs (Dial et al., 1984).

Factors involved in the development of the oestrogeninduced LH surge mechanism in pigs have not been fully defined.

${ }^{*}$ Correspondence

Received 30 March 1992.
Previous studies suggest an ovarian, probably oestrogendependent maturation of the positive feedback mechanism (Foxcroft et al., 1984). A significant reduction in the magnitude of oestradiol-induced LH surges on day 160 occurred in gilts ovariectomized on day 60 , compared with gilts ovariectomized on day 130 . Oestrogen therapy, after ovariectomy on day 60 , effectively restored the magnitude of the $\mathrm{LH}$ response. It also appears that the later stages of the maturation of the oestrogenpositive feedback mechanism are dependent on ovarian oestrogen and that continuous ovarian oestrogen stimulation is also necessary to maintain this function in pubertal gilts (Elsaesser et al., 1992).

Central inhibitory opioidergic systems have been found to be involved in the regulation of LH secretion in sows. Intracerebral or intravenous application of $\beta$-endorphin inhibits LH secretion in ovariectomized sows (Parvizi and Ellendorff, 1980) and endogenous opioids play an inhibitory role during the luteal phase, but not during other phases of the oestrous cycle (Barb et al., 1985, 1986a). During lactation endogenous opioids may be 
involved in the suckling-induced suppression of LH secretion (Barb et al., 1986b; Mattioli et al., 1986). The importance of the central opioidergic system for the generation of the preovulatory cyclic discharge of LH is debatable (Elsaesser et al., 1992) but studies in sexually mature rats suggest a role for opioid neurones in the timing and magnitude of the LH surge (Gabriel et al., 1986; Allen et al., 1988; Lustig et al., 1988). Endogenous opioids may also exert a restraining influence on the maturation of the positive feedback mechanism in this species (Faigon $e t$ al., 1987).

The purpose of the present study was to evaluate the role of endogenous opioids in the generation of $\mathrm{LH}$ surges in response to oestradiol benzoate in immature 60-day-old gilts by infusing various doses of the opioid antagonist naloxone during the surge period. In addition, we infused luteinizing-hormonereleasing hormone (LHRH) during the LH surge period in a pulsatile manner, to determine whether the pituitary can produce mature $\mathrm{LH}$ surge responses at this age.

\section{Materials and Methods}

\section{Animals}

German Landrace gilts, from the Institut für Tierzucht und Tierverhalten (FAL) experimental farm, aged 60 days (at the beginning of the experiments), were allocated randomly within litters to the various treatments. All gilts were surgically fitted with two indwelling jugular catheters (right and left external jugular veins) 4-5 days before the start of the experiments as described previously (Ellendorff et al., 1977). Gilts were then kept individually in animal crates in a purpose-built building under light $\left(12 \mathrm{~h}\right.$ light: $12 \mathrm{~h}$ dark) and temperature $\left(17^{\circ} \mathrm{C}-20^{\circ} \mathrm{C}\right)$ control and fed to appetite at $06: 30 \mathrm{~h}$ and 13:00 h.

\section{Experiment 1}

Thirty-six gilts aged $61 \pm 0.5$ days (mean \pm SEM), mean body weight $16 \pm 2 \mathrm{~kg}$ received $60 \mu \mathrm{g}$ oestradiol benzoate (Progynon B oleosum, $5 \mathrm{mg} \mathrm{ml}^{-1}$; Schering AG, Berlin) $\mathrm{kg}^{-1}$ body weight i.m. at $12.00 \mathrm{~h}$ and either received no further treatment $(n=4)$ or received continuous i.v. infusion of physiological saline solution from 49 to $97 \mathrm{~h}$ after oestradiol benzoate $(n=4)$, thus serving collectively as controls (group $1, n=8$ ); or received constant i.v. infusion of naloxone (Sigma, W-8024 Deisenhofen, Germany) at a rate of either $0.25 \mathrm{mg} \mathrm{kg}^{-1}$ body weight $\mathrm{h}^{-1}$ from 49 to $97 \mathrm{~h}$ after oestradiol benzoate (group 2, $n=7$ ); or $0.025 \mathrm{mg} \mathrm{kg}^{-1} \mathrm{~h}^{-1}$ from 49 to $97 \mathrm{~h}$ after oestradiol benzoate (group $3, n=8$ ); or $0.25 \mathrm{mg} \mathrm{kg}^{-1} \mathrm{~h}^{-1}$ from 49 to $55 \mathrm{~h}$ after oestradiol benzoate (group $4, n=7$ ); or $0.0025 \mathrm{mg}$ $\mathrm{kg}^{-1} \mathrm{~h}^{-1}$ from 49 to $63 \mathrm{~h}$ after oestradiol benzoate (group 5, $n=6$ ). Naloxone was administered at doses similar to or below those previously observed to elicit a decrease in plasma $\mathrm{LH}$ concentrations in newborn pigs $\left(0.5 \mathrm{mg}\right.$ naloxone $\mathrm{kg}^{-1}$; Prunier et al., 1990) or prepubertal gilts $\left(0.5 \mathrm{mg}\right.$ naloxone $\mathrm{kg}^{-1}$ at $1 \mathrm{~h}$ intervals; Cosgrove et al., 1991). The application design was intended to maintain naloxone in the circulation either during the onset $(49-55 \mathrm{~h})$, during the first part (49-63 h) or throughout the whole expected LH surge. Naloxone was dissolved in
$0.9 \%$ saline solution and infusions were performed through PVC extension tubings (3-4 $\mathrm{m}$ in length) at a rate of $5.8 \mathrm{ml} \mathrm{h}^{-1}$.

\section{Experiment 2}

Thirty-four gilts with a mean age of $60 \pm 0.2$ days and a mean weight of $17 \pm 3 \mathrm{~kg}$ were randomly allocated to the different treatment groups. Group I $(n=8)$ acted as collective controls and were challenged with $60 \mu \mathrm{g}$ oestradiol benzoate $\mathrm{kg}^{-1}$ body weight i.m. at $12.00 \mathrm{~h}$. Half of the animals of this group also received pulsatile infusion of saline solution at 35 min intervals $49-97 \mathrm{~h}$ after oestradiol benzoate. Group 2 $(n=7)$ received i.m. injections of sesame oil ( $2 \mathrm{ml})$ followed by pulsatile i.v. infusion of LHRH (Sigma, W-8024 Deisenhofen, Germany) in physiological saline solution from 49 to $97 \mathrm{~h}$ after sesame oil (pulse characteristics were $5 \mathrm{ng}$ LHRH kg ${ }^{-1}$ body weight at $35 \mathrm{~min}$ intervals). Group $3(n=8)$ animals received the same infusion but oestradiol benzoate $\left(60 \mu \mathrm{g} \mathrm{kg}^{-1}\right.$ body weight) was injected instead of sesame oil. LHRH was infused at 35 min intervals because it has been suggested that LH surges in the ewe are associated with secretion of LHRH in a pulsatile mode at a frequency of about two pulses $\mathrm{h}^{-1}$ (Clarke and Cummins, 1985). Group $4(n=4)$ received $60 \mu \mathrm{g}$ oestradiol benzoate $\mathrm{kg}^{-1}$ body weight and were fed methallibure (Suisynchron-Premix, VEB Serumwerke Bernburg, kindly provided by Forschungszentrum Dummerstorf-Rostock) to inhibit hypothalamic stimulation of $\mathrm{LH}$ secretion. Methallibure $(20 \mathrm{mg}$ per $100 \mathrm{~g}$ rations) was given daily before the morning feed for 4 days starting on day 1 after oestradiol benzoate treatment. Methallibure is thought to act centrally (Malven, 1971) and has been shown to block LH surges induced by oestradiol benzoate in mature ovariectomized gilts without compromising LH release in response to exogenous LHRH (Kesner et al., 1987). Group 5 $(n=7)$ were treated as group 4, but, in addition, received i.v. an LHRH agonist (LHRH-A; des-Gly ${ }^{10}\left[\mathrm{D}-\mathrm{Ala}{ }^{6}\right]$ LHRH ethylamide: Sigma) in $20 \mathrm{ng}$ boluses hourly from 49 to $97 \mathrm{~h}$ after oestradiol benzoate. This treatment was chosen because an identical LHRH-A regimen in ovariectomized gilts, in which the positive oestrogen feedback was blocked by either LHRH antiserum or human chorionic gonadotrophin, stimulated an LH surge that did not differ from oestradiol-primed controls (Britt $e t$ al., 1991; Ziecik et al., 1988). Infusions were performed through PVC tubings, 3-4 $\mathrm{m}$ in length. The infusion volume amounted to $2 \mathrm{ml}$ per pulse with a pulse duration of $1 \mathrm{~min}$. Either a Harvard or a Braun (Melsungen) pump was used for infusion.

\section{Blood sampling}

Blood samples $(2.5 \mathrm{ml})$ were taken every $4 \mathrm{~h}$ for analysis of LH starting at $25 \mathrm{~h}$ before and continuing until $119 \mathrm{~h}$ after i.m. injection of oestradiol benzoate or sesame oil (time 0 ). Additional blood samples were taken at $12 \mathrm{~h}$ intervals for determination of oestradiol. During dark phases red light forehead torches were used during sampling. Heparin was immediately added to samples which were then centrifuged for $20-30 \mathrm{~min}$ at $1000 \mathrm{~g}$ and plasma was stored at $-20^{\circ} \mathrm{C}$ until analysis. Haematocrit values of all animals were determined from the first and last blood samples. 


\section{Hormone analysis}

Plasma LH was determined in duplicate $100 \mu \mathrm{l}$ samples by an homologous radioimmunoassay described by Pomerantz et al. (1974) and Ponzilius et al. (1986). A specific antiserum (UCB Porcine-Anti-LH: UCB; Brussels, Belgium), which had been raised in rabbits against porcine $\mathrm{LH}$, was diluted $1: 80000$. Highly purified porcine LH (LER-786-3) had a biological activity of 0.65 NIH-LH-SIU $\mathrm{mg}^{-1}$ and was used for both the standard stock solution and for ${ }^{125}$ I-labelled hormone tracer. The sensitivity of the $\mathrm{LH}$ assay was $0.2 \mathrm{ng} \mathrm{ml}^{-1}$ plasma at the $90 \% \mathrm{~B}: \mathrm{B}_{0}$ level. The intra- and interassay coefficients of variation were 3.5 and 6.0, respectively. Gilts from different treatments were represented in each assay.

Plasma oestradiol was analysed by a specific radioimmunoassay (Elsaesser et al., 1978; Elsaesser and Parvizi, 1980). Oestradiol antiserum (E12) was obtained by immunizing rabbits against oestradiol-6-carboxy-o-methyl-oxime-BSA and diluted I:100 000. Crossreactions were: oestradiol benzoate, $1.5 \%$; oestrone $0.6 \%$, oestriol $0.1 \%$; and $<0.1 \%$ with progesterone, testosterone and hydrocortisone. Intra- and interassay variances were 9.0 and $13.3 \%$, respectively. Plasma volume for analysis was $500-2000 \mu \mathrm{l}$ in duplicate. The sensitivity of the assay at the $90 \% \mathrm{~B}: \mathrm{B}_{0}$ level was $4 \mathrm{pg} \mathrm{ml}^{-1}$ plasma when $2000 \mu \mathrm{l}$ plasma were used.

\section{Statistical analysis}

For evaluation of the results the whole experiment was divided on the basis of previous findings (Elsaesser and Foxcroft, 1978) into four periods: (1) pretreatment from 25 to $\mathrm{I} \mathrm{h}$ before oestradiol benzoate injection at $\mathrm{Oh},(2)$ negative feedback from 3 to $47 \mathrm{~h}$, (3) positive feedback from 51 to $95 \mathrm{~h}$ and (4) post surge from 99 to $119 \mathrm{~h}$. Mean LH values were calculated for each period and each animal and these means were used to detect differences between the experimental periods within and between treatment groups.

All data were analysed using the SPSS/PC + program (SPSS, Inc., 1986). Experiment 1 was conducted in three replicates and Expt 2 was conducted in two replicates, and each of the replicates involved control animals. As there were no differences among replicates in response to control treatment, data from all replicates were pooled for statistical analysis. Data were tested for normal distribution (Kolmogorov-Smirnov test) and homogeneity of variances (Bartletts test). In case of homogeneous variance, ANOVA was followed by the Scheffe test. Otherwise the data were evaluated using the Kruskal-Wallis test.

\section{Results}

Since no differences were observed between control gilts, with and without physiological saline infusion in Expt 1 and Expt 2 $(P>0.05)$, these animals were considered as one group.

\section{Concentration of oestradiol in plasma}

Mean pretreatment concentrations of oestradiol in plasma (Fig. 1) were low $\left(<4-8 \mathrm{pg}\right.$ oestradiol $\left.\mathrm{ml}^{-1}\right)$. Twelve hours after treatment with oestradiol benzoate, concentrations had

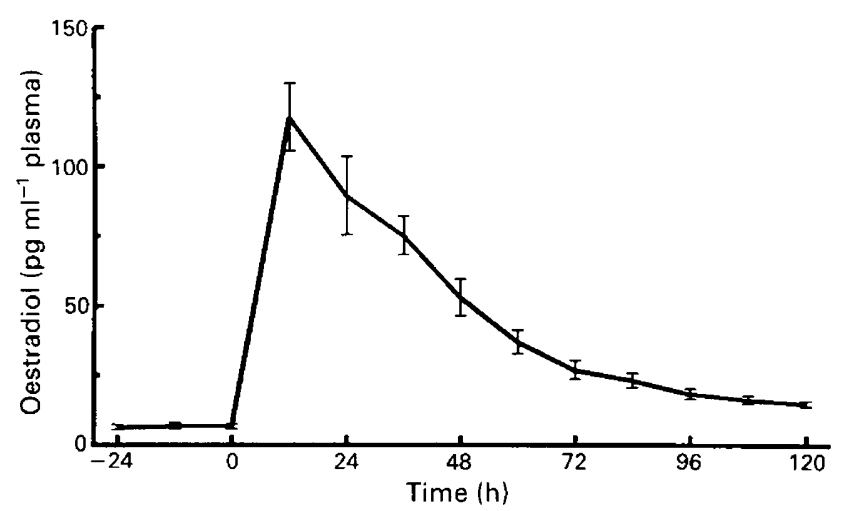

Fig. 1. Mean \pm SEM plasma oestradiol concentrations in 60-day-old gilts $(n=70)$ before and after i.m. administration of oestradiol benzoate $\left(60 \mu \mathrm{g} \mathrm{kg}^{-1}\right.$ body weight). The lower limit of sensitivity was $4 \mathrm{pg}$ oestradiol $\mathrm{ml}^{-1}$ plasma.

increased to $120 \pm 6 \mathrm{pg}$ oestradiol $\mathrm{ml}^{-1}$; thereafter, concentrations decreased, remaining above pretreatment values for the remainder of the sampling period.

\section{Effect of naloxone infusion}

Plasma LH concentrations before and after oestradiol benzoate treatment varied considerably within treatment groups. During the initial period after oestradiol benzoate treatment (negative feedback), mean LH concentrations were suppressed, although this was not statistically significant in all groups (Table 1; Fig. 2). Individual $\mathrm{LH}$ concentrations during this period were often below the sensitivity of the $\mathrm{LH}$ radioimmunoassay. Oestradiol benzoate then produced modest LH surges (positive feedback), which were typically biphasic, with peak LH concentrations occurring during darkness. During this period, mean LH concentrations were higher $(P<0.05)$ than in the previous period, except for the gilts of group 2, but were not different from pretreatment concentrations except for group 4 (Table 1). However, for all groups, maximum surge concentrations were raised compared with maximum pretreatment $\mathrm{LH}$ concentrations $(P<0.05)$. With the exception of those gilts that were infused with naloxone for $48 \mathrm{~h}$, the negative feedback of oestradiol was again apparent between 99 and $119 \mathrm{~h}$ after oestradiol benzoate treatment $(P<0.05$ compared with the surge period).

Although there was a tendency for higher maximum LH surge concentrations in gilts infused for $48 \mathrm{~h}$ with $0.025 \mathrm{mg}$ naloxone $\mathrm{kg}^{-1} \mathrm{~h}^{-1}$, none of the naloxone treatments affected the characteristics of the induced LH surges significantly. Neither mean LH concentration during the surge period, nor maximum surge concentrations, nor time to peak LH concentrations were different among treatment groups (Table 1).

\section{Effect of pulsatile LHRH infusion}

The secretory pattern of LH release was highly variable within treatment groups. Pulsatile LHRH infusion following sesame oil injection induced a rapid increase in plasma LH concentrations, resulting in higher LH concentrations at $51 \mathrm{~h}$ 
Table 1. Mean ( \pm SEM) concentrations of LH in plasma $\left(\mathrm{ng} \mathrm{ml}^{-1}\right)$ before and after challenging gilts with oestradiol benzoate and infusion of naloxone

\begin{tabular}{|c|c|c|c|c|c|}
\hline Naloxone infusion dose $\left(\mathrm{mg} \mathrm{kg}^{-1} \mathrm{~h}^{-1}\right)^{*}$ & 0 & 0.25 & 0.025 & 0.25 & 0.0025 \\
\hline Duration of naloxone infusion (h) & & 48 & 48 & 6 & 14 \\
\hline$n$ & 8 & 7 & 8 & 7 & 6 \\
\hline \multicolumn{6}{|l|}{ LH concentration $\left(\mathrm{ng} \mathrm{ml}^{-1}\right)$} \\
\hline Pretreatment concentrations $(-25$ to $-1 \mathrm{~h})$ & $0.48 \pm 0.10^{\mathrm{a}}$ & $0.34 \pm 0.06$ & $0.63 \pm 0.12^{\mathrm{a}}$ & $0.33 \pm 0.05^{\mathrm{a}}$ & $0.60 \pm 0.09^{\mathrm{a}}$ \\
\hline Negative feedback concentrations ( 3 to $47 \mathrm{~h}$ ) & $0.22 \pm 0.03^{\mathrm{a}, \mathrm{f}}$ & $0.23 \pm 0.03$ & $0.21 \pm 0.02^{\mathrm{a} . \mathrm{b}}$ & $0.21 \pm 0.01^{\ell}$ & $0.21 \pm 0.02^{\mathrm{ad}}$ \\
\hline Mean surge concentrations (51 to $95 \mathrm{~h}$ ) & $0.62 \pm 0.08^{\mathrm{cf}}$ & $0.45 \pm 0.09$ & $0.77 \pm 0.21^{b}$ & $0.70 \pm 0.13^{\text {a e.f }}$ & $0.74 \pm 0.16^{\mathrm{c.d}}$ \\
\hline Post surge concentrations ( 99 to $119 \mathrm{~h}$ ) & $0.26 \pm 0.04^{c}$ & $0.49 \pm 0.13$ & $0.51 \pm 0.15$ & $0.26 \pm 0.03^{e}$ & $0.25 \pm 0.17^{c}$ \\
\hline Maximum pretreatment concentrations & $0.91 \pm 0.18^{d}$ & $0.71 \pm 0.14^{\mathrm{d}}$ & $1.00 \pm 0.15^{\mathrm{d}}$ & $0.78 \pm 0.12^{d}$ & $1.10 \pm 0.17^{b}$ \\
\hline Maximum surge concentrations & $1.65 \pm 0.21^{d}$ & $1.60 \pm 0.24^{\mathrm{d}}$ & $2.78 \pm 0.50^{\mathrm{d}}$ & $2.01 \pm 0.37^{d}$ & $2.04 \pm 0.34^{\mathrm{b}}$ \\
\hline Time to maximum surge concentrations (h) & $75 \pm 4$ & $88 \pm 8$ & $81 \pm 8$ & $74 \pm 5$ & $69 \pm 4$ \\
\hline
\end{tabular}

*Naloxone infusion started at $49 \mathrm{~h}$ after oestradiol benzoate $\left(60 \mu \mathrm{g} \mathrm{kg}^{-1}\right.$ body weight).

Means within a column with the same superscript letter are different ( ${ }^{\mathrm{ab}}: p<0.05$; ${ }^{\text {cd.e. }}: p<0.01$; $: p<0.001$ ).

after sesame oil injection compared with controls or animals challenged with oestradiol benzoate and infused with LHRH $(P<0.05$, Fig. 3). Furthermore, in sesame oil plus LHRHtreated gilts, mean plasma LH concentrations during pulsatile LHRH infusion ( +49 to $+97 \mathrm{~h}$ ) were higher than pretreatment concentrations $(P<0.05)$ and maximum LH concentrations during this period differed from maximum pretreatment concentrations $(P<0.05$, Table 2$)$.

Pulsatile LHRH infusion in gilts treated with oestradiol benzoate did not change the characteristics of the oestradiol benzoate-induced LH surges. Neither mean LH concentrations during the surge period, maximum surge concentrations, nor time to peak $\mathrm{LH}$ concentrations were different from these parameters in control animals.

Feeding methallibure suppressed the oestradiol benzoateinduced LH surge as maximum LH concentrations $49-97 \mathrm{~h}$ after oestradiol benzoate were not different from respective concentrations before oestradiol benzoate (Table 2, Fig. 3). Mean surge concentrations were lower $(P<0.05)$ than those in controls, and methallibure plus LHRH-A-treated gilts and maximum surge concentrations were below $(P<0.05)$ those of all other groups. Pulsatile LHRH-A infusion every hour in methalliburetreated gilts restored plasma $\mathrm{LH}$ concentrations to those of controls. Time to maximal LH surge concentrations, however, was reduced to $64 \mathrm{~h}(P<0.05$ compared with controls) because $\mathrm{LH}$ peak concentrations always occurred during the first night of the surge period. Thus, the biphasic surge response to oestradiol benzoate, typical for immature gilts, was abolished.

\section{Discussion}

A substantial body of evidence suggests a requirement for central input in the generation of the oestrogen-induced LH surge in the mature sow. Anaesthesia with pentobarbitone during pro-oestrus-oestrus inhibits the LH surge in sows (Parvizi et al., 1976) and an LH surge can be induced by oestradiol benzoate treatment in female but not in male pigs (Elsaesser et al., 1978; Elsaesser and Parvizi, 1979). Furthermore, an LH surge induced by oestrogen is blocked by feeding methallibure, a compound thought to act centrally without compromising LH release in response to exogenous LHRH (Kesner et al., 1987). Likewise, the oestrogen-induced $\mathrm{LH}$ release in the immature gilt was blunted by methallibure (this study). Most probably, LHRH is the signal from the central nervous system (CNS) to trigger the $\mathrm{LH}$ surge. Whether the input from the CNS, required for the induction of the LH surge in the mature sow, is under inhibitory control by endogenous opioids as suggested by studies in rats using the opioid antagonist naloxone (Gabriel et al., 1986; Allen et al., 1988; Lustig et al., 1988) is debatable (Elsaesser et al., 1992).

Naloxone can increase tonic LH secretion in mature sows during the luteal phase of the oestrous cycle (Barb et al., 1985, 1986b) and during lactational anoestrus (Barb et al., 1986a; Mattioli et al., 1986; Armstrong et al., 1988). However, naloxone failed to alter tonic $\mathrm{LH}$ concentrations in prepubertal gilts (Barb et al., 1988) and even a paradoxical inhibitory effect on LH secretion has been observed with naloxone in newborn male and female piglets (Prunier et al., 1990) and prepubertal gilts (Cosgrove et al., 1991). In this study, naloxone failed to clearly affect the characteristics of $\mathrm{LH}$ surges induced by oestradiol benzoate. Naloxone infusion doses were similar to or below those previously used by Prunier et al. (1990) or Cosgrove $e t$ al. (1991) and the start of the naloxone infusions was well in advance of the onset of the LH surge in control gilts. Naloxone, although doses were low compared with other studies (Armstrong et al., 1988; Barb et al., 1985, 1986a), was effective in the post-surge period when it was infused for $48 \mathrm{~h}$. If opioids play a major role in the prevention of mature $\mathrm{LH}$ surges at this age, one of the naloxone application regimens should therefore have yielded a response. These findings in the immature gilt are in contrast to findings in rats, in which the development of the positive feedback mechanism of ovarian hormones on $\mathrm{LH}$ secretion is apparently advanced by naloxone (Faigon et al., 1987).

In animals infused for $48 \mathrm{~h}$ with naloxone, LH secretion did not decrease in the post-surge period, in contrast to the other groups. This could indicate that endogenous opioids are involved in mediating the negative feedback action of oestrogen. However, available evidence in the sexually mature pig (Barb et al., 1988) does not support this view. Alternatively, endogenous opioids may play a role in the termination of oestrogen-induced hypersecretion of $\mathrm{LH}$ as suggested for the rat (Gabriel et al., 1986). In Expt 2 LH secretion decreased after 

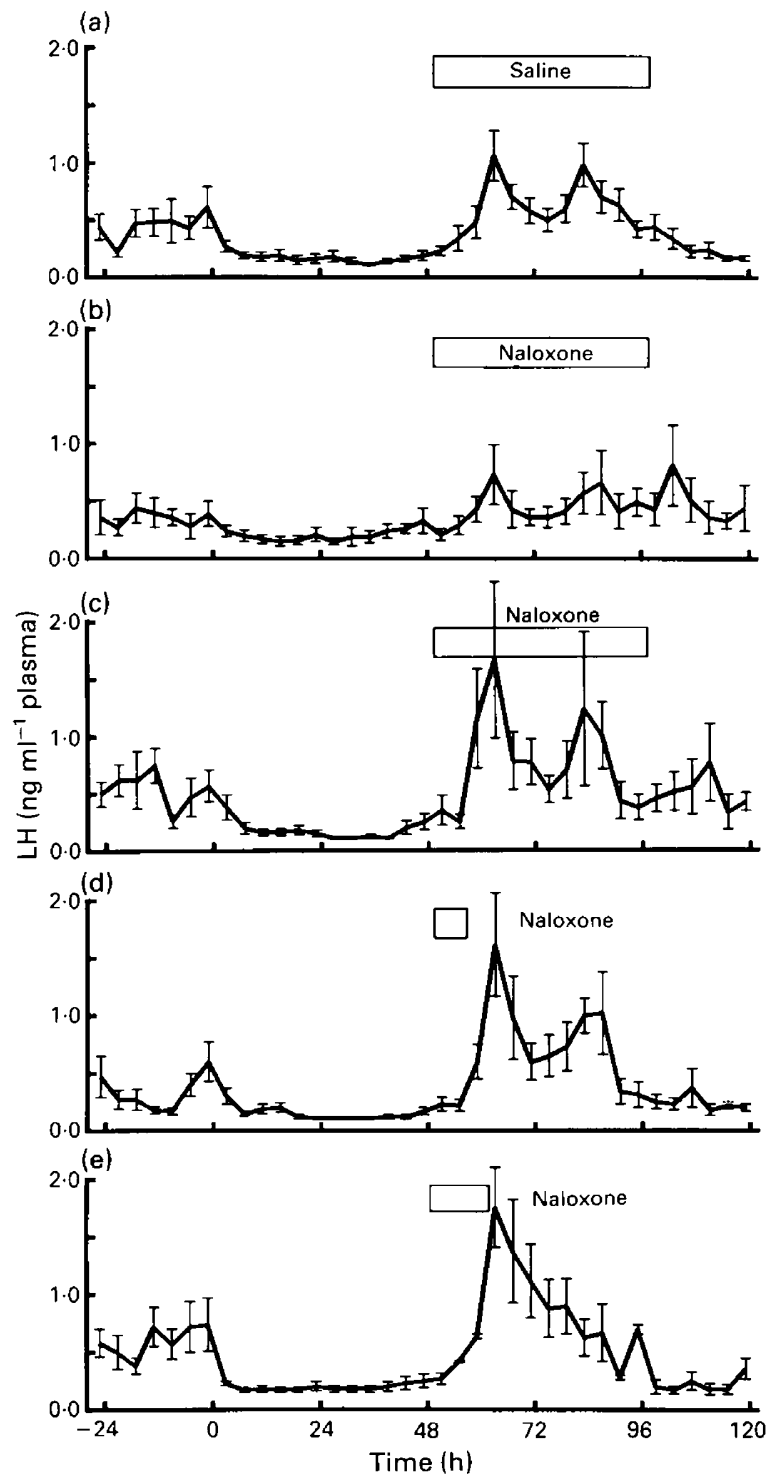

Fig. 2. Mean \pm SEM plasma concentrations of LH in 60-day-old gilts given oestradiol benzoate ( $60 \mu \mathrm{g} \mathrm{kg}^{-1}$ body weight) and infused with (a) physiological saline solution or various doses of naloxone: (b) $0.25 \mathrm{mg} \mathrm{kg}^{-1} \mathrm{~h}^{-1}$ for $48 \mathrm{~h}$, (c) $0.025 \mathrm{mg} \mathrm{kg}^{-1} \mathrm{~h}^{-1}$ for $48 \mathrm{~h}$, (d) $0.25 \mathrm{mg}$ $\mathrm{kg}^{-1} \mathrm{~h}^{-1}$ for $6 \mathrm{~h}$ and (e) $0.0025 \mathrm{mg} \mathrm{kg}^{-1} \mathrm{~h}^{-1}$ for $14 \mathrm{~h}$. There were no significant differences at any time point among any of the treatments $(P>0.05$, ANOVA).

the LH surge, although pulsatile infusion of LHRH continued; this would suggest that there is some sort of refractoriness at the pituitary level. Potentially this refractoriness could be affected by naloxone, but it is unlikely that the effect of naloxone is at the level of the hypothalamus. In this respect Barb et al. (1990) have shown opioid modulation of LH secretion by pig pituitary cells in vitro.

Pulsatile LHRH infusion after oil treatment increased LH concentrations within $2 \mathrm{~h}$ after the start of infusion and at that time (51 h after oil) $\mathrm{LH}$ concentrations were significantly higher than in the control group or in animals receiving the same LHRH infusion but oestradiol benzoate instead of oil. This observation suggests that in the immature gilt pituitary responsiveness to
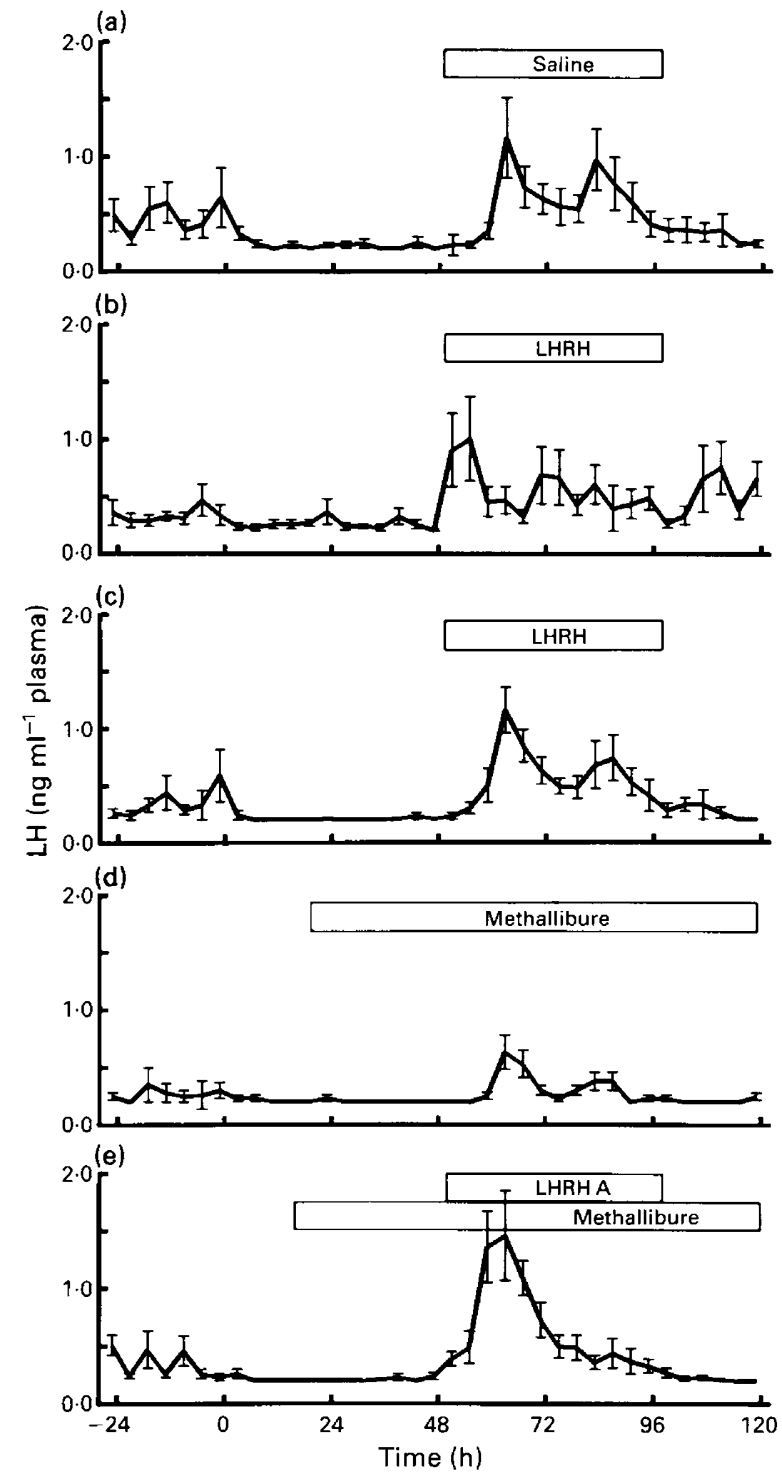

Fig. 3. Mean \pm SEM plasma concentration of $\mathrm{LH}$ in 60-day-old gilts following various treatments: (a) control, $60 \mu \mathrm{g}$ oestradiol benzoate $\mathrm{kg}^{-1}$ body weight, (b) sesame oil and pulsatile infusion of LHRH from 49 to $97 \mathrm{~h}$, (c) oestradiol benzoate and pulsatile infusion of LHRH, (d) oestradiol benzoate and methallibure from 20 to $119 \mathrm{~h}$ to suppress $\mathrm{LH}$ secretion and (e) oestradiol benzoate, methallibure and pulsatile infusion of an LHRH agonist (LHRH-A). Significant differences $(P<0.05$, ANOVA) were observed at $51 \mathrm{~h}$ between group 2 (b) and group 3 (c), at $59 \mathrm{~h}$ between group 1 (a) and group 5 (e), at $67 \mathrm{~h}$ between group 2 (b) and group 5 (e), at 115 h between group 2 (b) and groups 3 (c), 4 (d) and 5 (e) and at $119 \mathrm{~h}$ between group 2 (b) and all the other groups.

LHRH is decreased by oestrogen immediately before the onset and maybe throughout the whole period of the LH surge. Foxcroft et al. (1975) and Pomerantz et al. (1975) report that oestrogen causes a depression of pituitary responsiveness to exogenous LHRH up to 3 days after immature 12- to 13-weekold gilts were implanted with oestradiol capsules. In contrast, in the sexually mature sow, $\mathrm{LH}$ response to LHRH is inhibited for only $12-20 \mathrm{~h}$ after oestradiol benzoate administration (Cox and Britt, 1982; Kesner et al., 1987). 
Table 2. Mean ( \pm SEM) concentrations of $\mathrm{LH}$ in plasma $\left(\mathrm{ng} \mathrm{ml}^{-1}\right)$ before and after challenging gilts with oestradiol benzoate and pulsatile infusion of $\mathrm{LHRH}$

\begin{tabular}{|c|c|c|c|c|c|}
\hline Treatment & $\begin{array}{l}\text { Oestradiol } \\
\text { benzoate } \\
\pm \text { saline }\end{array}$ & Oil + LHRH ${ }^{\dagger}$ & $\begin{array}{l}\text { Oestradiol } \\
\text { benzoate } \\
+\mathrm{LHRH}^{\dagger}\end{array}$ & $\begin{array}{l}\text { Oestradiol } \\
\text { benzoate } \\
+ \text { methallibure }\end{array}$ & $\begin{array}{c}\text { Oestradiol } \\
\text { benzoate }+ \text { methallibure } \\
+ \text { LHRH-A } \text { A }_{+}^{+}\end{array}$ \\
\hline$n$ & 8 & 7 & 8 & 4 & 7 \\
\hline $\begin{array}{l}\text { Pretreatment concentrations } \\
(-25 \text { to }-1 \mathrm{~h})\end{array}$ & $0.48 \pm 0.06^{\mathrm{A}}$ & $0.34 \pm 0.03$ & $0.35 \pm 0.05^{A}$ & $0.29 \pm 0.03^{A}$ & $0.35 \pm 0.04^{\mathrm{A}}$ \\
\hline $\begin{array}{l}\text { Negative feedback } \\
\text { concentrations ( } 3 \text { to } 47 \mathrm{~h} \text { ) }\end{array}$ & $0.23 \pm 0.01^{\mathrm{A.E}}$ & $0.26 \pm 0.01^{\mathrm{a}, \mathrm{b}, \mathrm{A} A \mathrm{~A}}$ & $0.21 \pm 0.01^{\mathrm{a}, \mathrm{A} . \mathrm{E}}$ & $0.21 \pm 0.01^{\mathrm{b} . \mathrm{A}}$ & $0.21 \pm 0.01^{c, A, E}$ \\
\hline $\begin{array}{l}\text { Mean surge concentrations } \\
\text { (51 to } 95 \mathrm{~h} \text { ) }\end{array}$ & $0.60 \pm 0.06^{\mathrm{a}, \mathrm{C} . \mathrm{E}}$ & $0.58 \pm 0.06^{A}$ & $0.58 \pm 0.04^{C, E}$ & $0.32 \pm 0.03^{\mathrm{ab}}$ & $0.66 \pm 0.06^{b . C . E}$ \\
\hline $\begin{array}{l}\text { Post surge concentrations } \\
\text { ( } 99 \text { to } 119 \mathrm{~h})\end{array}$ & $0.31 \pm 0.03^{\mathrm{a}, \mathrm{C}}$ & $0.52 \pm 0.07^{\mathrm{a}, \mathrm{e}, \mathrm{fg}}$ & $0.26 \pm 0.03^{e, C}$ & $0.21 \pm 0.01^{\mathrm{f}}$ & $0.22 \pm 0.01^{g . C}$ \\
\hline $\begin{array}{l}\text { Maximum pretreatment } \\
\text { concentrations }\end{array}$ & $0.90 \pm 0.21^{\mathrm{D}}$ & $0.91 \pm 0.15^{\mathrm{B}}$ & $0.62 \pm 0.15^{D}$ & $0.55 \pm 0.19$ & $0.69 \pm 0.14^{D}$ \\
\hline $\begin{array}{l}\text { Maximum surge } \\
\text { concentrations }\end{array}$ & $1.62 \pm 0.18^{\mathrm{a}, \mathrm{D}}$ & $1.83 \pm 0.28^{\mathrm{b}, \mathrm{B}}$ & $1.37 \pm 0.16^{\mathrm{co}}$ & $0.65 \pm 0.13^{a, b, c, d}$ & $1.76 \pm 0.17^{\mathrm{d}, \mathrm{D}}$ \\
\hline $\begin{array}{l}\text { Time to maximum LH surge } \\
\text { concentrations }(\mathrm{h})\end{array}$ & $76 \pm 3^{a}$ & $78 \pm 9^{b}$ & $72 \pm 5$ & $66 \pm 4$ & $64 \pm 3^{a, b}$ \\
\hline
\end{tabular}

*Oestradiol benzoate, $60 \mu \mathrm{g} \mathrm{kg}^{-\mathrm{r}}$ body weight.

$\div 5 \mathrm{ng} \mathrm{LHRH} \mathrm{kg}^{-1}$ body weight at 35 min intervals from 49 to $97 \mathrm{~h}$ after oestradiol benzoate.

$\$$ LHRH-A: LHRH agonist, des-Gly ${ }^{10}\left[\mathrm{D}-\mathrm{Ala} \mathrm{a}^{\mathrm{o}}\right]$ LHRH ethylamide, $20 \mathrm{ng}$ per animal at $1 \mathrm{~h}$ intervals from 49 to $97 \mathrm{~h}$ after oestradiol benzoate.

Means within a row with the same superscript are different (a.b.c.d: $P<0.05$, e.tg: $P<0.01$ ).

Means within a column with the same superscript letter are different $\left({ }^{A . B}: P<0.05,{ }^{C D}: P<0.01,{ }^{\mathrm{E}}: P<0.001\right)$.

The failure of pulsatile LHRH administration to elicit an oestradiol benzoate-induced LH surge similar to that seen in pubertal or sexually mature gilts could be due to an inappropriate LHRH treatment regimen or to failure of the gonadotrophs to respond to LHRH at this age in an adultlike manner or to both factors. The exact nature of the LHRH stimulus (pulse frequency and amplitude) necessary to elicit an oestrogeninduced LH surge in the mature sow is not known. In hypophysial stalk-transected gilts, an unvarying pulsatile infusion of LHRH during the surge period did not significantly increase serum LH concentrations beyond those of controls not given oestradiol (Kesner et al., 1989a). This finding was interpreted to suggest that the magnitude of the LH surge in pigs is determined mainly by the magnitude by which oestradiol augments CNS input, that is, LHRH. Indeed, before the onset of the LH surge, LHRH content within the medial basal hypothalamus and stalk-median eminence is increased $36 \mathrm{~h}$ after gilts have received oestradiol (Cox and Britt, 1982).

In gilts in which the positive oestrogen feedback was blocked either by passive immunization against LHRH (Britt et al., 1991) or injection of hCG (Ziecik et al., 1988), an LH surge that was not different from the surge induced in oestradiol benzoate-treated controls could be evoked by hourly injections of an LHRH agonist for 54-96 h after oestradiol benzoate treatment. Treatment with the same dose per $\mathrm{kg}$ body weight, and identical frequencies of the same LHRH agonist in this study overcame the inhibition of the LH surge produced by methallibure and restored the magnitude of the surge to that of controls. However, an LH surge amplitude similar to that seen in pubertal gilts (Elsaesser and Foxcroft, 1978) or achieved by this LHRH-agonist treatment regimen in mature gilts (Ziecik et al., 1988; Britt et al., 1991) was not generated. This finding points to the pituitary as the site that limits the full expression of the $\mathrm{LH}$ surge in the immature gilt, although our studies did not include pubertal or sexually mature gilts with which to directly compare the LH responses of immature gilts. In the mature gilt, oestradiol augments gonadotroph responsiveness to LHRH during the surge period (Britt et al., 1991; Kesner et al., 1989b) and increases pituitary stores of LH immediately before the surge (Cox and Britt, 1982). Possibly these regulatory mechanisms are not fully established in the immature gilt.

A biphasic or even triphasic positive $\mathrm{LH}$ response to oestradiol is typical for the immature gilt (Elsaesser and Foxcroft, 1978; Dial et al, 1984; Foxcroft et al., 1984). A change to a single surge response to oestradiol is reported to occur before pubertal gilts become cyclic (Dial et al., 1984) and apparently this late maturational change of the positive oestrogen feedback also depends on ovarian oestrogen (Elsaesser et al., 1992). In gilts treated with methallibure plus LHRH agonist, the multiphasic LH surge response changed to a monophasic response, despite continued pulsatile LHRH agonist infusion. Thus, the LH surge induced by oestradiol benzoate is terminated for reasons other than a lack of LHRH, indicating that the gonadotrophs become refractory to LHRH. Refractoriness may be due to a depletion of a releasable pool of $\mathrm{LH}$ or desensitization. Although experimental evidence to support these suggestions is lacking in pigs, a depletion of pituitary LH content and a reduction in the number of pituitary LHRH receptors were observed at the end of the LH surge in ewes (Crowder and Nett, 1984). Continuous pulsatile infusion of the potent LHRH agonist might have desensitized the gonadotrophs by 
downregulation of the LHRH receptor, thereby terminating the LH surge. In this regard, it has been shown that continuous infusion of LHRH to ewes can decrease the number of their receptors (Nett et al., 1981).

In conclusion, central inhibitory opioidergic systems do not seem to be of major importance in preventing mature LH surge responses to oestradiol benzoate at 60 days of age. Apparently, oestradiol fails to generate mature LH surges because the gonadotrophs of immature gilts cannot respond to enhanced LHRH secretion during the surge period in an adult-like manner. Whether this inability is due to a lack of or insufficient accumulation of readily releasable LH pools necessary for the generation of the $\mathrm{LH}$ surge or failure of oestradiol to augment gonadotroph responsiveness to LHRH or to both factors is unknown.

\section{References}

Allen LG, Hahn E, Caton D and Kalra SP (1988) Evidence that a decrease in opioid tone on proestrus changes the episodic pattern of luteinizing hormone (LH) secretion: implications in the preovulatory $\mathrm{LH}$ hypersecretion Endocrinology 122 1004-1013

Armstrong JD, Kraeling RR and Britt JH (1988) Effects of naloxone or transient weaning on secretion of LH and prolactin in lactating sows Journal of Reproduction and Fertility 83 301-308

Barb CR, Kraeling RR, Rampacek GB and Whisnant CS (1985) Opioid inhibition stimulates luteinizing hormone and prolactin secretion in the gilt Domestic Animal Endocrinology 2 93-98

Barb CR, Kraeling RR, Rampacek GB and Whisnant CS (1986a) Influence of stage of the estrous cycle on endogenous opioid modulation of luteinizing hormone, prolactin, and cortisol secretion in the gilt Biology of Reproduction $35 \quad 1162-1167$

Barb CR, Kraeling RR, Rampacek GB and Whisnant CS (1986b) Opioid inhibition of luteinizing hormone secretion in the postpartum lactating sow Biology of Reproduction 35 368-371

Barb CR, Rampacek GB, Kraeling RR, Estienne MJ, Taras E, Estienne CE and Whisnant CS (1988) Absence of brain opioid peptide modulation of luteinizing hormone secretion in the prepubertal gilt Biology of Reproduction 39 603-609

Barb CR, Barrett JB, Wright JT, Kraeling RR and Rampacek GB (1990) Opioid modulation of $\mathrm{LH}$ secretion by pig pituitary cells in vitro Journal of Reproduction and Fertility $90213-219$

Britt JH, Esbenshade KL and Ziecik AJ (1991) Roles of estradiol and gonadotropin-releasing hormone in controlling negative and positive feedback associated with luteinizing hormone surge in ovariectomized pigs Biology of Reproduction 45 478-485

Clarke IJ and Cummins JT (1985) Increased gonadotropin-releasing hormone pulse frequency associated with estrogen-induced luteinizing hormone surges in ovariectomized ewes Endocrinology 116 2376-2383

Cosgrove JR, Booth PJ and Foxcroft GR (1991) Opioidergic control of gonadotrophin secretion in the prepubertal gilt during restricted feeding and realimentation Journal of Reproduction and Fertility 91 277-284

Cox NN and Britt JH (1982) Effect of estradiol on hypothalamic GnRH and pituitary and serum LH and FSH in ovariectomized pigs Joumal of Animal Science 55 901-908

Crowder ME and Nett TM (1984) Pituitary content of gonadotropins and receptors for gonadotropin-releasing hormone $(\mathrm{GnRH})$ and hypothalamic content of GnRH during the periovulatory period of the ewe Endocrinology 114 234-239

Dial GD, Dial OK, Wilkinson RS and Dziuk PJ (1984) Endocrine and ovulatory responses of the gilt to exogenous gonadotropins and estradiol during sexual maturation Biology of Reproduction 30 289-299

Ellendorff F, Parvizi N, Elsaesser F and Smidt D (1977) The miniature pig as an animal model in endocrine and neuroendocrine studies of reproduction Laboratory Animal Science $27822-830$

Elsaesser F and Foxcroft GR (1978) Maturational changes in the characteristics of oestrogen-induced surges of luteinizing hormone in immature domestic gilts Joumal of Endocrinology 78 455-456
Elsaesser F and Parvizi N (1979) Estrogen feedback in the pig: sexual differentiation and the effect of prenatal testosterone treatment Biology of Reproduction 20 1187-1193

Elsaesser F and Parvizi N (1980) Partial recovery of the simulatory oestrogen feedback action on LH release during late lactation in the pig Joumal of Reproduction and Fertility $5963-67$

Elsaesser F, Parvizi N and Ellendorff F (1978) Steroid feedback on luteinizing hormone secretion during sexual maturation in the pig Joumal of Endocrinology 78 329-342

Elsaesser F, Parvizi N and Foxcroft GR (1992) Control of the LH surge mechanism in the female pig Journal of Physiology and Pharmacology $\mathbf{4 3}$ (Supplement 1) 69-78

Faigon MR, Szwarcfarb B, Scacchi P and Moguilevsky JA (1987) Effect of naloxone on the development of the positive feed-back action of oestrogenprogesterone on LH secretion in rats Acta Endocrinologica 115 16-20

Fleming MW and Dailey RA (1985) Longitudinal study of the surge of gonadotropins induced by exogenous hormones in prepuberal gilts Endocrinology 116 1893-1898

Foxcroft GR, Pomerantz DK and Nalbandov AV (1975) Effects of estradiol-17 $\beta$ on LH-RH/FSH-RH-induced, and spontaneous, LH release in prepubertal female pigs Endocrinology 96 551-557

Foxcroft GR, Elsaesser F, Stickney K, Haynes NB and Back HL (1984) Ovarian oestrogen-dependent maturation of the LH/FSH surge mechanism during prepubertal development in the gilt Journal of Endocrinology 101 371-380

Gabriel SM, Berglund LA and Simpkins JW (1986) A decline in endogenous opioid influence during the steroid-induced hypersecretion of luteinizing hormone in the rat Endocrinology 118 558-561

Kesner JS, Kraeling RR, Rampacek GB and Johnson B (1987) Absence of an estradiol-induced surge of luteinizing hormone in pigs receiving unvarying pulsatile gonadotropin-releasing hormone stimulation Endocrinology 121 1862-1869

Kesner IS, Estienne MJ, Kraeling RR and Rampacek GB (1989a) Luteinizing hormone and prolactin secretion in hypophysial-stalk-transected pigs given estradiol and pulsatile gonadotropin-releasing hormone Neuroendocrinology 49 502-508

Kesner JS, Price-Taras EA, Kraeling RR, Rampacek GB and Barb CR (1989b) Negative feedback as an obligatory antecedent to the estradiol-induced luteinizing hormone surge in ovariectomized pigs Biology of Reproduction 41 409-413

Lustig RH, Pfaff DW and Fishman J (1988) Opioidergic modulation of the oestradiol-induced LH surge in the rat: roles of ovarian steroids Joumal of Endocrinology 116 55-69

Malven PV (1971) Hypothalamic sites of action of methallibure (ICI 33828) inhibition of gonadotropin secretion Joumal of Animal Science $32912-918$

Mattioli M, Conte F, Galeati G and Seren E (1986) Effect of naloxone on plasma concentrations of prolactin and $\mathrm{LH}$ in lactating sows Journal of Reproduction and Ferfility 76 167-173

Nett TM, Crowder ME, Moss GE and Duello TM (1981) GnRH-receptor interaction. V. Down-regulation of pituitary receptors for GnRH in ovariectomized ewes by infusion of homologous hormone Biology of Reproduction 24 $1145-1155$

Parvizi N and Ellendorff F (1980) $\beta$-Endorphin alters luteinizing hormone secretion via the amygdala but not the hypothalamus Nature $286 \quad 812-813$

Parvizi N, Elsaesser F, Smidt D and Ellendorff F (1976) Plasma luteinizing hormone and progesterone in the adult female pig during the oestrous cycle, late pregnancy and lactation, and after ovariectomy and pentobarbitone treatment Journal of Endocrinology 69 193-203

Pomerantz DK, Ellendorff F, Elsaesser F, König A and Smidt D (1974) Plasma LH changes in intact adult, castrated adult and pubertal male pigs following various doses of synthetic luteinizing hormone-releasing hormone (L.H-RH) Endocrinology 94 330-335

Pomerantz DK, Foxcroft GR and Nalbandov AV (1975) Acute and chronic estradiol-17 $\beta$ inhibition of $\mathrm{LH}$ release in prepubertal female pigs: time course and site of action Endocrinology 96 558-563

Ponzilius K-H, Parvizi N, Elsaesser F and Ellendorff F (1986) Ontogeny of secretory patterns of LH release and effects of gonadectomy in the chronically catheterized pig fetus and neonate Biology of Reproduction 34 602-612

Prunier A, Ellendorff F and Parvizi N (1990) Opioid action on luteinizing hormone secretion in newborn pigs: paradoxical effect of naloxone Journal of Developmental Physiology 14 221-227

SPSS Inc. (1986) SPSS/PC + . McGraw-Hill Book Company, New York

Ziecik AJ, Britt JH and Esbenshade KL (1988) Short loop feedback control of the estrogen-induced luteinizing hormone surge in pigs Endocrinology 122 1658-1662 